\title{
Global Ideologies, Local Politics: The Cold War as Seen from Central Angola
}

\section{Justin PEARCE}

(University of Cambridge)

International rivalry in the Cold War has dominated scholarship on the postindependence war in Angola, but little research has been done on how foreign support for the Popular Movement for the Liberation of Angola (MPLA) and the National Union for the Total Independence of Angola (UNITA) had an impact on political mobilisation inside Angola. This article draws upon interviews with people who remembered the conflicts of the 1970s and 1980s in the Angolan Central Highlands, the area in which UNITA made its strongest identity-based claims against the MPLA state, and which was fiercely contested during the war. It compares these with memoirs and other secondary material that record elite perspectives on the war. I argue that ideologies espoused by the external players in Angola had little direct impact on the political affiliations of people in the contested area. Nevertheless, external support for rival movements in Angola indirectly shaped and polarised popular attitudes towards the movements, notably by providing the MPLA and UNITA with the capacity to present themselves as state-like.

Much of the history of Angola from independence in 1975 until the end of the Cold War has been written as a narrative of foreign intervention. If ideology is mentioned in relation to the war, this usually refers to the global ideologies of the Cold War, alongside an assumption that the ideologies of the MPLA and UNITA were congruent with those of their foreign allies. The relationship between these global ideologies and popular mobilisation has been neglected. ${ }^{1}$ The purpose of this article, therefore, is to consider the relationship between Angolan and global politics from a different perspective, by examining the impact of Cold War alliances on the thinking of Angolan elites and on processes of political mobilisation and political identity formation in Angola.

Through the 1980s and 1990s, a large part of the writing by foreign journalists and scholars on the Angolan conflict and its international connections was driven by opposition to apartheid in South Africa. ${ }^{2}$ This literature assumes popular support for the MPLA, views UNITA as being driven not by internal Angolan concerns but by its duties as a South African and US proxy, and ignores UNITA's engagement with civilian society in the parts of Angola that it controlled. Other writers, who were ideologically opposed to communism, celebrated UNITA and took for granted its

\footnotetext{
1 The same is true for the literature on the wider southern African region during the Cold War, with the notable exception of work that examines the the impact of the Cold War international context on the internal ideologies of settler state regimes. See D. Lowry, 'The Impact of Anti-Communism on White Rhodesian Political Culture, ca. 1920s -1980', Cold War History, 7, 2 (2007), pp. 169-94; J. Miller, 'Things Fall Apart: South Africa and the Collapse of the Portuguese Empire, 1973-74', Cold War History, 12, 2 (2012), pp. 183-204.

2 Two journalistic accounts are V. Brittain, Death of Dignity: Angola's Civil War (London, Pluto Press, 1998) and M. Wolfers and J. Bergerol, Angola in the Front Line (London, Zed Books, 1983). Scholarly treatments include W. Minter, Apartheid's Contras: An Inquiry into the Roots of War in Angola and Mozambique (London, Zed Books, 1994) and G. Wright, The Destruction of a Nation: United States' Policy Toward Angola Since 1945 (London, Pluto Press, 1997).
} 
legitimacy as a representative of an Angolan nation. ${ }^{3}$ Both groups of writers' concern with international interests leaves scant space to consider political strategy within Angola. ${ }^{4}$

Since the 1990s, our understandings of the motivations for and consequences of American, Soviet, Cuban and South African involvement in Angola and in other conflicts have been enriched by the flowering of historical research on the Cold War, made possible by newly accessible archives. A common thread in this literature concerns the ideological motivations of the intervening powers. For Westad, the US and the Soviet Union were driven respectively by an ideology of individual freedom that evolved into an imperative 'to make the world safe for capitalism', 5 and by a version of socialist ideology in which 'the competition for influence in the Third World was an essential part of the existence of socialism'. ${ }^{6}$ Gleijeses emphasises Cuba's autonomy from the Soviet Union's agendas, and sees Cuban interventions in Africa as motivated above all by a vision of a 'world that was dominated ... by the conflict between privileged and underprivileged, humanity against imperialism' and where the major fault line was 'not between socialist and capitalist states but between developed and undeveloped countries'. ${ }^{7}$ Central to such analysis is the fact that decolonisation coincided temporally with the Cold War. If modernity is about the extension of the reach of states and the efforts by states to shape societies, the space for ideological influence by the Cold War powers was to be found in the projects of state-building and nation-building that accompanied decolonisation. As Westad notes, 'the revolutions that followed were often inspired by either the Soviet or American form of high modernism, ${ }^{8}$ However, this wave of literature is little concerned with the internal politics of Angola and other countries that were sites of foreign intervention.

While questions of local ideology and popular participation in Cold War-era African conflicts are barely present in the literature on global history, such questions dominate a separate body of scholarship that takes a national or sub-national perspective. Histories of the Zimbabwean war of independence and the Mozambican post-independence war, for example, rely on interview as well as documentary sources and have addressed questions about the nature of and motivations for participation in those conflicts. ${ }^{9}$ More recent scholarship has started to investigate the

3 The pre-eminent journalist account is F. Bridgland, Jonas Savimbi: A Key to Africa (Edinburgh, Mainstream, 1986), though an earlier example is F. Sitte, Flammenherd Angola (Vienna, Kremayr und Scheriau, 1972).

4 Shafer's comment on literature about the Mozambican guerrilla movement, Renamo, is pertinent also to Angola and UNITA: 'scholars analyzing Renamo's success at anchoring itself in the countryside initially attempted to find explanations which denied the role of civilian support, because of their overriding belief that Renamo was not ideologically motivated, but rather a puppet of the apartheid regime', J. Shafer, 'Guerrillas and Violence in the War in Mozambique: De-Socialization or Re-Socialization?', African Affairs, 100, 399 (2001), p. 216. A rare exception is the work of Heywood, who examines the longer historical roots of UNITA's social relations in Angola: L. Heywood, 'UNITA and Ethnic Nationalism in Angola', Journal of Modern African Studies, 27, 1 (1989) pp. 47-66; L. Heywood, 'Towards an Understanding of Modern Political Ideology in Africa: The Case of the Ovimbundu of Angola', Journal of Modern African Studies, 36, 1 (1998) pp. 139-67; L. Heywood, Contested Power in Angola: 1840s to the Present (Rochester, University of Rochester Press, 2002).

5 O. Westad, The Global Cold War (Cambridge, Cambridge University Press, 2005), p. 31.

6 Ibid., p. 72.

7 P. Gleijeses, Conflicting Missions: Havana, Washington and Africa 1959-1976 (Chapel Hill and London, University of North Carolina Press, 2002), p. 377.

8 Westad, The Global Cold War, p. 397.

9 On Zimbabwe, see T. Ranger, Peasant Consciousness and Guerrilla War in Zimbabwe: A

Comparative Study (London, James Currey, 1985); N. Kriger, Zimbabwe's Guerrilla War: Peasant 
'transnational and non-national' nature of armed conflict in southern Africa, which had previously been studied within the epistemological frames of 'national liberation'. ${ }^{10}$ Beyond southern Africa, conflict studies developed as a crossdisciplinary sub-field of study during the 1990s. While some strands within this literature concentrate on resource predation or on state weakness, most pertinent to my perspective here is that part of the literature on conflict that brings ideology back into the analysis: ideology not in the sense of the global ideologies of the Cold War, but in the sense of the structured understandings that endow actions with meaning. If the task of 'political entrepreneurs', to use Tilly's term, is 'the activation and reinforcement of boundaries', the creation and consolidation of perceptions of 'we' and 'them', ${ }^{11}$ then ideological appeals are one part of this process. Such appeals, imbricated with ideas and narratives about the past and the present that frame understandings about the relationship between the individual and the political movement, may be manipulated by political actors in order to shape perceptions of solidarity and enmity. In Broch-Due's words, '[i]ndividuals and groups call on cultural and historical narratives, arguments and ideologies, to challenge established parameters and reinforce their claims to legitimacy'. ${ }^{12}$ However, close-up studies of political mobilisation in wartime are rare in the case of Angola. ${ }^{13}$ What is more, in scholarship on southern Africa more broadly, there has been no dialogue between the burgeoning literature on global history and the literature that deals with conflict in relation to mobilisation around national and sub-national identities.

In this article, I bridge that gap by investigating the impact of the Cold War upon local politics in Angola during the civil war. I consider how and to what extent the rivalry between the superpowers, and the fact of Cuban or South African support for the rival Angolan movements, influenced the politicising efforts of the MPLA and of UNITA, and how people responded to them. My primary concern here is with how the elites associated with the rival political movements sought to shape perceptions of popular interest to political ends, and how people perceived and expressed their own relationship with the MPLA and UNITA. This is not to say that political identities were uniformly strong, nor that they remained fixed throughout the civil war. The strongest self-identification with a political movement is, naturally, expressed by elites on one or other side, and by people who spent the entire war in territory

Voices (Cambridge, Cambridge University Press, 1992); J. Alexander, J. McGregor and T. Ranger, Violence and Memory: One Hundred Years in the 'Dark Forests' of Matabeleland (Oxford, James Currey, 2000). On Mozambique, see A. Nilsson, 'From Pseudo-Terrorists to Pseudo-Guerillas: The MNR in Mozambique', Review of African Political Economy, 20, 57 (1993) pp. 60-71; C. Geffray, La Cause des Armes au Mozambique: Anthropologie d'une Guerre Civile (Paris, Karthala, 1990); R. Gersony, Summary of Mozambican Refugee Accounts of Principally Conflict-Related Experience in Mozambique (Washington DC, Department of State Bureau for Refugees, 1998); Margaret Hall, 'The Mozambican National Resistance Movement (RENAMO): A Study in the Destruction of an African Country', Africa, 60, 1 (1990), pp. 39-68. Michel Cahen, 'Dhlakama é maningue nice!: An Atypical Former Guerrilla in the Mozambican Electoral Campaign', Transformation, 35 (1998), pp. 1-48; J. McGregor, 'Violence and Social Change in a Border Economy: War in the Maputo Hinterland 19841992', Journal of Southern African Studies, 24, 1 (1998) pp. 37-60; Alex Vines, Renamo: Terrorism in Mozambique (London, James Currey, 1991).

10 L. White and M. Larmer, 'Introduction: Mobile Soldiers and the Un-National Liberation of Southern Africa', Journal of Southern African Studies, 40, 6 (2014) pp. 1271-4.

11 C. Tilly, The Politics of Collective Violence (Cambridge, Cambridge University Press, 2003), p. 75. 12 V. Broch-Due, 'Violence and Belonging: Analytical Reflections', in V. Broch-Due (ed.), Violence and Belonging: The Quest for Identity in Post-Colonial Africa (London, Routledge, 2005), p. 10. 13 Gleijeses, Conflicting Missions, p. 235, and Minter, Apartheid's Contras, p. 271, point out how little is known about the politics of mobilisation in Angola, owing to practical difficulties in research. 
controlled by only one political movement. But many Angolans experienced the control of the MPLA and of UNITA at different times in the war. They had no choice but to profess loyalty to whichever movement was in charge at that moment. ${ }^{14}$ It is for this reason that I use the word 'adherent' rather than 'supporter' of a political movement, since 'support' suggests too great a degree of voluntary affiliation. ${ }^{15}$ Within these processes of politicisation, I find that the Cold War had consequences for local Angolan politics in ways that were related only tangentially to the ideological positions of the movements' international allies.

In contrast to many studies of civil war the principal burden of which is to explain the emergence of the rebel movement, I focus simultaneously on the MPLA and UNITA. ${ }^{16}$ This approach reflects the fact that UNITA did not rise up in rebellion against the MPLA. Rather, both movements started out in opposition to Portuguese colonial rule. Following the precipitate departure of the Portuguese and the defeat of the National Front for the Liberation of Angola (FNLA) in 1975, the MPLA and UNITA each found itself in control of a part of the Angolan territory and population. Each used this physical control as the basis for making its rule hegemonic. The process of consolidating hegemony was two-sided: each movement sought to present itself as worthy of support, and at the same time to create perceptions of enmity towards the other movement by presenting it as opposed to the common good.

Elsewhere I have argued that ideas about state building were at the core of the ideologies propagated by the MPLA and UNITA as they sought to legitimise their rule, and were internalised to a greater or lesser extent by the people who lived in the areas controlled by those two rival movements. ${ }^{17}$ UNITA, as well as the MPLA, was aware of the importance of portraying itself in a state-like manner. I draw upon Philip Abrams's argument that 'the idea of the state' may be of more significance than the state itself and that the state 'is first and foremost an exercise in legitimation', and on the argument of Hansen and Stepputat that 'languages of stateness' may be politically persuasive. ${ }^{18}$ Hence to the belligerents in civil war, stateness is more than simply the goal of or aspiration to statehood: it is a tool for the legitimation of political authority by the government and its opponents alike, within the territory controlled by each. Ideas of stateness are a central part of the ideologies that defined the relationship between people and political entities, whether that entity be a recognised state, such as the state led by the MPLA, or an organisation that makes state-like claims, such as UNITA. These include the organisation's responsibilities in providing for the welfare of the nation, its role as defender of the nation and its prerogatives of violence in fulfilling this role. People who lived under either or both movements during the course of their lives evoked ideas about stateness, whether explicitly or implicitly, in

14 This observation about the relationship between military control and political identity echoes the findings of S. Kalyvas, The Logic of Violence in Civil War (Cambridge, Cambridge University Press, 2006). These issues as they pertain to Angola are discussed more fully in J. Pearce, 'Control, Politics and Identity in the Angolan Civil War', African Affairs, 111, 444 (2012) pp. 442-65.

15 In Portuguese, the term 'aderência' (literally, adherence) is used to describe the following of a political movement. People were described, and described themselves, as 'povo da UNITA' or 'povo do governo /povo do MPLA' ('UNITA people' or 'government/MPLA people').

16 On the tendency to 'criminalise' the rebel movement, see R. Marchal and C. Messiant, 'Une Lecture Symptomale de Quelques Théorisations Récentes des Guerres Civiles', Revue Lusotopie, 13, 2 (2006), pp. 3-46.

17 Pearce, 'Control, Politics and Identity'.

18 P. Abrams, 'Notes on the Difficulty of Studying the State (1977)', Journal of Historical Sociology 1, 1 (1988), pp. 58-98; Thomas Blom Hansen and Finn Stepputat, States of Imagination: Ethnographic Explorations of the Postcolonial State (Durham, Duke University Press, 2001). 
their accounts of the politics of the war and of their identification with either or both political movements. I argue therefore that it is in and through ideologies of stateness, more than through the official ideologies of the Cold War, that the foreign presence in Angola in support of the MPLA and of UNITA made an impact on local political relationships during the civil war. Foreign support was important in that it provided the material conditions for the rival Angolan parties to consolidate their legitimacy by making a reality of stateness.

The next two sections will consider ways in which the MPLA's links with Cuba and UNITA's various foreign connections were represented in the official discourse of each party, and in interviews with people in the Angolan Central Highlands on the subject of the war years. The interviewees include people of varying class positions and levels of education, people from the city of Huambo and farmers from rural villages, and people who had spent all or part of the war years under the control of UNITA, as well as people who had spent their entire lives in governmentcontrolled areas. I consider how these factors shaped the way in which people perceived and spoke of the Cuban and South African presence, and the roles of the Angolan political movements and their foreign allies. My use of sources in the two sections is not symmetrical: the section on Cuba and the MPLA relies more heavily on interviews, while the section on UNITA's alliances makes greater use of elite writings. This reflects a different emphasis in the two sections. For the MPLA, its relationship with Cuba caused no anxiety for the elite, but the presence of Cubans in Angola elicited differing reactions from ordinary people. On the UNITA side, the elite was ambivalent about its former links with China and anxious over the political consequences of its relationship with South Africa, while for most Angolans in UNITA-held areas, the Chinese were absent and the South Africans barely present.

\section{Cuba and the MPLA}

The MPLA's relationship with Cuba originated in informal contacts in the late 1950s at the Casa dos Estudantes do Império, the residence in Lisbon for students from the Portuguese empire, which became a centre of left-wing opposition to the Salazar regime. ${ }^{19}$ Cuba saw internationalism as an extension of its own revolution and its opposition to US ambitions. ${ }^{20}$ As Cuba established missions in 'radical' African capitals such as Algiers, Dar es Salaam and Brazzaville during the 1960s, there was occasional contact between Cuban and MPLA officials in those cities. The MPLA first sought the help of Cuban military instructors in 1965. The MPLA ideologue Lúcio Lara said that the MPLA 'wanted Cuban instructors because of the prestige of the Cuban revolution and because their theory of guerrilla warfare was very close to our own'. ${ }^{21}$ Cuban support enabled MPLA guerrillas to infiltrate Cabinda and the Dembos region, north of Luanda, between 1965 and 1967, though the ultimate failure of these operations caused the relationship to cool. ${ }^{22}$ Nevertheless, it was to Cuba that the MPLA turned in 1975 as a South African invasion in support of UNITA, and the Zaire-based FNLA forces, threatened to oust the party after its declaration of independence in Luanda. The Cuban military intervention in November safeguarded the MPLA's hold on Luanda by destroying the FNLA army, and by halting the South African invasion force. While Cuban troops continued to provide security in the years

19 E. George, The Cuban Intervention in Angola, 1965-1991: From Che Guevara to Cuito Cuanavale (London, Frank Cass, 2005), p. 22.

20 George, The Cuban Intervention, p. 14.

21 Gleijeses, Conflicting Missions, p. 83.

22 Ibid., pp. 174-82, 244. 
that followed, Cuban teachers and medical staff constituted the backbone of Angolan state service provision. ${ }^{23}$

Histories of the relationship between the MPLA and Cuba have been written largely from Cuban sources, and concentrate on Cuban perceptions of the relationship. An exception is Mabeko-Tali's account, which notes that the MPLA justified the Cuban intervention in terms of a sovereign state's right under the UN Charter to seek military assistance against foreign aggression. But the MPLA also used 'another justification, simultaneously emotional and ideological, more so than historical: Cuban fighters returned to Angola in the quality of the descendants of African slaves'. The MPLA's justification for Cuban assistance rested 'on the theme of the struggle against imperialism', summed up in a phrase coined by Fidel Castro and repeated by officials of both countries: 'what counts is not geography but ideology'. ${ }^{24}$ Angolan officials would speak of the two states as partners in a way that partly obscures the one-way flow of assistance. The Angolan President, José Eduardo dos Santos, on receiving the José Martí medal in Havana in 1980, spoke of 'our friendship, consolidated in the trenches, reinforced in the battle for national reconstruction, shoulder to shoulder' and 'relations with the Republic of Cuba and with other countries of the socialist community, our policy of co-operating with all the countries of the world that respect the principle of non-interference'. ${ }^{25}$

Yet the alliance was less consistent than the rhetoric. Gleijeses suggests that Agostinho Neto, Angolan president from 1975 until his death in 1979, wished to reduce dependence on Cuba in order to cultivate a better relationship with the west, but also relied on Cuba to fend off South African aggression. ${ }^{26}$ By 1981, Lúcio Lara was lamenting the decline of a once 'brotherly' relationship and calling for it to be restored in the face of renewed US and South African threats. ${ }^{27}$ Cuba indeed retained its role as the MPLA's security guarantor through the 1980s. Dos Santos, in his speeches and interviews, continued to insist that the South African invasion had been defeated 'thanks to the militant participation of internationalists like the fighting comrades of $\mathrm{Cuba}^{, 28}$ and that 'Cuban co-operation was always very important to our country, and in various sectors', including education, health, civil construction and agriculture. ${ }^{29}$ Notwithstanding the occasional mismatch between rhetoric and reality, the MPLA's discourses at home and on the international stage were mutually consistent. Unlike the UNITA elite, which, as we shall see, was ever anxious about its unsavoury relationship with apartheid South Africa, MPLA leaders comfortably shared with their Cuban counterparts a language of internationalism and third world solidarity.

For people in the Central Highlands, their first contact with Cubans was when Cuban forces alongside the MPLA's People's Armed Forces for the Liberation of Angola (FAPLA) occupied the region's main towns in February 1976. Their arrival

23 'Between November 1975 and 1976, 36,000 Cuban soldiers poured into Angola.... Their number peaked at 55,000 in 1988'; by 1978, there were nearly 7,000 Cuban aid workers in Angola, including teachers, construction workers and health staff. Gleijeses, Visions of Freedom, pp. 9, 84.

24 J-M. Mabeko-Tali, Dissidências e Poder de Estado: O MPLA Perante Si Próprio (1962-1977) Vol. 2: 1974-1977 (Luanda, Nzila, 2001), pp. 132-3. Mabeko-Tali's account benefits from unique access to the personal papers of Lúcio Lara. All translations from Portuguese written sources in this article are my own.

25 J.E. dos Santos, A Luta do Povo pela Unidade e pelo Socialismo (Lisbon, Avante, 1985), p. 26.

26 Gleijeses, Visions of Freedom, p. 103.

27 Ibid., p. 194.

28 Dos Santos, A Luta, p. 30.

29 Ibid., p. 168. 
was facilitated by the retreat of South African troops, who had been providing backup to UNITA. ${ }^{30}$ Military assistance to the MPLA was followed by the arrival of Cuban professionals, whose expertise was crucial to the MPLA's efforts to build state institutions. ${ }^{31}$ The remainder of this section considers the ways in which the Cuban presence was remembered and recounted by the people whom I interviewed, taking into account both the political convictions of the interviewee, and the circumstances in which the interviewee encountered the Cubans.

Among the most ideologically committed interviewees, attitudes to the Cubans ran concurrent with broader political loyalties. Such interviewees parroted the party line of one side or the other: they serve as a reference point by which to understand the more nuanced or ambivalent views expressed in other interviews. One interviewee was a soba (chief), appointed to a position in a peri-urban bairro of Huambo. ${ }^{32}$ ProMPLA politicisation appeared to have been particularly strong here, as the bairro had been a resettlement area for people displaced during government counter-insurgency operations, and this had an impact on how people recounted their history in the postwar period in which I was researching. The soba spoke of having been 'captured' to serve in the MPLA's armed forces while employed as a contract labourer in northern Angola in the 1960s. This 'capture' had nevertheless cemented his identification with the MPLA, and he habitually dressed in the party colours: 'the MPLA called the Cubans to join our armed struggle. We were friends, great friends. No one spoke ill of the Cubans. To this day, the Cubans are great friends'. ${ }^{33}$

The fact that memories of the Cubans were still politically loaded in that village became evident during an interview with another man in the same location. This interviewee, who had been conscripted to fight for the MPLA in the late 1970s, complained that the Cubans 'just stole things from the people, ate our food. In battle they stayed behind and the Angolans were pushed to the front' ${ }^{34}$ This version of events provoked a reaction from bystanders eavesdropping on the interview, who interrupted the interviewee, insisting that 'the Cubans were our brothers'.

More educated interviewees spoke of the Cuban involvement in a way that reflected the party discourse, as in the case of a civil servant who had spent his life in the service of the MPLA: "the Cubans at that time were taking part in the proletarian struggle, to win against colonialism and especially capitalism. They were always people well disposed to helping those who were in difficult situations. We felt this: in war, at school, in the hospitals they were with us'. ${ }^{35}$

To move from one set of extreme views to the opposite, some of the strongest anti-Cuban sentiments were expressed by people who had been with UNITA in wartime, and who remained part of the networks of former UNITA combatants after the war, which provided a space to recount narratives of the war contrary to the MPLA version. These people were adamant that Cuba had invaded Angola, and for this reason they had joined UNITA to defend the Angolan nation. This view was repeated so consistently that it was clear that it had been a theme in UNITA's political

30 Gleijeses, Conflicting Missions, p. 342.

31 D. Birmingham, 'Angola', in P. Chabal (ed.), A History of Postcolonial Lusophone Africa (London, Hurst, 2002), p. 150.

32 Bairro in Angola usually refers to a poor outlying neighbourhood, sometimes semi-rural. Although the succession of sobas is supposedly on the basis of lineage and community discussion, in practice it has been subject to political interference.

33 Interview with a village chief, Huambo, May 2008. All interviews for this article were conducted by the author.

34 Interview, farmer, Huambo, May 2008.

35 Interview, civil servant, Huambo, June 2008. 
education. The Cuban presence was useful to UNITA in bolstering its nationalist claims by casting the enemy as the agent of foreign forces. ${ }^{36}$

One woman I interviewed had been a young adult working in Huambo at the time of independence. She recalled running away from Huambo as the Cubans advanced in February 1976: 'when the MPLA entered Huambo with the Cuban forces we thought they were coming to persecute the UNITA people. Many were killed. We went back [to the city] when it was returning to normal'. ${ }^{37}$ 'Normal', however, proved to be relative. 'The Cubans would take people's animals. The people lived with oppression. This is why many people preferred UNITA and made the revolution underground. The Cubans and Angolans [MPLA] co-operated in oppression. The Cubans raped women - anyone who said no to them would be punished. After returning to Huambo she continued to work underground for UNITA in the city, arranging for supplies to be delivered to guerrillas in the bush and for information and propaganda from UNITA to be circulated in the city. Later she left Huambo to re-join UNITA in the countryside, where she worked in UNITA's health services.

The examples noted so far illustrate the two poles of opinion about the Cuban presence in Angola. The speakers were people who, through their work as activists or as cadres attached to the MPLA or to UNITA, had come to accept unquestioningly the preferred discourse of one or the other party about historical events and about the relationship of the two parties to Angolan society. For many other interviewees, however, their perception of the Cubans and of the role they played was shaped not by politicisation within party structures but rather by the circumstances in which they encountered Cuban soldiers or cooperantes. The Cuban presence was far from uniform throughout Angola. The MPLA state comprised islands of control surrounded by countryside that was either controlled by UNITA or perpetually contested between the two armies. Even within this archipelago-like state, the Cubans clustered only in the urban centres of each 'island'. It was in places like Huambo city, a centre of MPLA state-led development that was all but isolated amid countryside in which UNITA moved freely, that the Cubans made the greatest impact. The MPLA sought to win the support of the urban population through the provision of services, and the Cubans provided the technical expertise that made this role possible. In the words of a lawyer who had been a young man in the mid-1970s:

When the MPLA appeared in 1976 it appeared with the Cubans - with a different type of organisation, a more supported organisation, to distinguish it from UNITA, which had a more backward society, of a lower level. [...] This brought a bit more stability, which as time went on convinced people that things were moving in a positive direction. ${ }^{38}$

As an educated man, this interviewee was able to articulate clearly what was implicit in many other interviews: that the MPLA built its legitimacy on its ability to construct a state and that the Cubans were central to the project of state building. Being a lawyer, he worked in a state system that was closely associated with the party, so it is not surprising that his ideological frame of reference corresponds to the official one, but his conclusions are also grounded in his experience of life in the city under MPLA control.

36 Bridgland describes a piece of UNITA propaganda theatre in which Agostinho Neto strikes a bargain with Leonid Brezhnev and Fidel Castro, and Cuban soldiers slaughter Angolan peasants until being defeated by UNITA. Bridgland, Jonas Savimbi, p. 313.

37 Interview, farmer, Huambo, July 2008.

38 Interview, lawyer, Huambo, May 2008. 
Some other urban interviewees were well disposed towards the Cubans despite not having close connections with the MPLA:

the Cubans lived together well with the people. They left sons and daughters. Everyone knew they were foreigners, but there were no limits to how we could live together. They had a different status. They had their own separate shops, but you could also see Cubans shopping in the market. ${ }^{39}$

This was due in part to a perception of Cubans as protectors. 'Wherever the Cubans were, there was stability. UNITA didn't attack there. The Cubans didn't impose themselves ideologically on the population. They helped, helped a lot. They lived apart from us, but socially they were very friendly' ${ }^{40}$ Not all of these interviewees explicitly attributed a political agenda to either the Cubans or the MPLA.

Nevertheless, as urban people, from modest backgrounds but reasonably well educated, these people enjoyed some benefit from Cuban development or security provision.

In those peri-urban villages that fell within the MPLA's security zone, villagers were marginal to the ambitions of the state and the party. Some, like the soba quoted earlier, had come to accept the party's views about its status as the defender of Angolan citizens against a common enemy. This had been the experience of another interviewee who had lived on the fringes of Huambo as a teenager in the 1970 s and as a young woman in the 1980s. When asked about the Cuban presence, she spoke first of the Cubans' military role. 'They were the army. Their programme was to fight against the enemy, which was UNITA. They went around the bush in their vehicles looking for the enemy - we remained in our bairros ${ }^{41}$ 'Only when asked whether there were also Cubans in civilian life did she reply: 'they also worked. They helped in the hospital, curing the sick. In all the departments they helped a lot. Some were soldiers, others civil servants. They did their work of development here in the civil service'. Her acceptance of the Cubans, even if their presence had little direct impact on her life, contrasts with the views of people in more marginal peri-urban or rural areas, whose lives were untouched by the MPLA state-building project.

Another of my interview sites was a village on the outskirts of the city of Huambo. Typical comments here were 'everything that the Cubans found they killed or took by force' or 'everyone took cattle: the government and UNITA'. ${ }^{42}$ According to these interviewees, the Cubans had difficulty with the fact that all Angolans were the same colour, hence it was difficult for them to spot the enemy. The result of this was that the Cubans were suspicious towards all Angolans, particularly those whose language, Umbundu, marked them as being from the same ethnic group as Jonas Savimbi.

Some of the men in this group had been conscripted into the FAPLA, but their experience of combat had only deepened their resentment of Cubans. 'It was an international war. The MPLA with the Cubans, UNITA with the South Africans. But it was mostly Angolans who died. Only a few Cubans died. They pushed us to the front. They'd say "you are the master of this land"'. These were people who had never been exposed to UNITA's politicisation. Yet although they had lived under MPLA control as soldiers or as civilians, the fact that they saw little benefit from the

39 Interview, development worker, Luanda, October 2008.

40 Interview, priest, Huambo, September 2008.

41 Interview, farmer, Huambo, May 2008.

42 Group interview with farmers, Huambo, October 2008. 
MPLA's state-building project gave them no reason to view the Cubans with anything other than suspicion.

People's attitudes towards the Cubans were determined by the circumstances in which they encountered them. But the flatly contradictory statements about the Cubans that emerged in interviews sometimes appeared to have been a matter of interpretation rather than a matter of fact. The Cubans mixed well with the Angolans despite living in separate quarters - or their privileged existence only bred alienation and resentment from Angolans. When Cuban soldiers fathered the children of Angolan women, this was interpreted by some as a sign of the Cubans' integration into Angolan society and by others as evidence of their propensity to rape. Some believed that the fact that the Cubans spoke Spanish, a language related to Portuguese, helped them to integrate, while others insisted that the fact that they spoke neither Portuguese nor Umbundu kept them apart from Angolans.

People who lived in the cities were more likely to have enjoyed the benefits that the Cubans brought in terms of welfare and development. Yet city people who had strong pro-UNITA convictions dating from before independence were more likely to regard the MPLA's developmental efforts with suspicion, and see the Cubans as proof of the foreign nature of the MPLA. These two factors were mutually reinforcing: experience of the Cubans moulded people's political views, while political convictions also coloured how interviewees interpreted the Cubans' role.

\section{UNITA: From Beijing to Pretoria}

In 1976, Jonas Savimbi and some of his generals were on holiday in Namibia as the guests of the South African Defence Force. Samuel Chiwale, who would later become the commander of UNITA's armed forces, recalls the visit in his memoir.

It was there, in South West Africa, that we received the news of the death of Mao Tse-Tung, the president of China.

'We have lost a great friend and a great ally', said Dr Savimbi. 'But let us not be despondent and let us hope for whoever will replace him'....

We spent a few days swimming, and in between swimming and the well-earned rest that we could now enjoy, we discussed with General Malan, General Foliun [Viljoen] and Brigadier Skuman [Schoeman] the strategy to adopt to put down the red invasion. ${ }^{43}$

Mourning Mao while consorting with apartheid generals provides a vivid illustration of the UNITA leadership's opportunistic attitude to its foreign connections. UNITA's links with China began soon after Savimbi's break from the FNLA to found UNITA in 1966. Maoist ideas informed Savimbi's strategy of mobilising rural communities during the anti-colonial war. ${ }^{44}$ In 1967 , Mao had advised Savimbi to establish a rear base in the remote woodlands of eastern Angola, as well as establishing a 'fish in water' relationship with the peasants of the more densely populated Central Highlands. ${ }^{45}$ This dual strategy, learnt from Mao, addressed both the need to operate in an environment where the population was large enough to allow UNITA to recruit people to its cause - what Savimbi called 'the theory of big numbers' - and the need for a remote base that was safe from attack by the MPLA government. ${ }^{46}$

43 S. Chiwale, Cruzei-me com a História (Lisbon, Sexante Editora, 2008), p. 239.

44 J. Marcum, The Angolan Revolution, Volume 2 (Exile Politics and Guerrilla Warfare, 1962-1976)

(Cambridge, Mass., MIT Press, 1978), p. 195.

45 Interview, Jaka Jamba, Luanda, September 2009.

46 S. Chiwale, Cruzei-me, pp. 243-4, 253. 
South Africa's interest in Angola was heightened when the Portuguese coup of 25 April 1974 raised the prospect of independence for Portugal's African colonies, which had formed a security cordon for the apartheid state. As the three rival Angolan movements vied for position after the coup, fears about the MPLA's leftward orientation prompted South Africa to intervene by providing limited military training to UNITA and the FNLA during 1974, before committing itself to UNITA in the second half of 1975. By August, the departure of Portuguese forces from Angola's southern border prompted South Africa to take control of the extreme south of the country. In October, South Africa launched a full-scale invasion in an attempt to expel the MPLA from Luanda by the scheduled independence date of 11 November. This force was repelled by Cuban soldiers, who had arrived in response to a plea from the MPLA.

UNITA, meanwhile, attempted to establish a government in Huambo, where it had seized control in mid 1975, though it barely managed to keep the remnants of the colonial state operating. When Angola officially became independent at midnight on 10 November, Jonas Savimbi was in Pretoria, meeting South Africa's Prime Minister, J.B. Vorster. According to a South African Defence Force account, Vorster said that South Africa would remain in Angola as long as it could keep the Cubans at bay. ${ }^{47}$ The memoir of the UNITA official Jardo Muekalia reads this conditional pledge as providing an opt-out for South Africa were things to get tough. This was due in part to the lack of enthusiasm from the US to provide diplomatic cover for South Africa, and partly because Vorster preferred seeking détente to confrontation with South Africa's neighbours. ${ }^{48}$

By February, once South Africa had withdrawn to within 50 miles of the Angola-Namibia border, UNITA had no means of defending its position in the Central Highlands. A former associate of Savimbi recalls him saying: 'we don't know how to choose our friends. The United States is not our friend. If we'd chosen the Russians we'd be in Luanda by now' ${ }^{49}$ As the Cuban and FAPLA soldiers approached from the coast, UNITA soldiers, officials and civilian adherents left the Central Highland cities that they had occupied and headed east to their redoubts from the anti-colonial war in Moxico province.

There followed an episode that was to become mythologised in UNITA's accounts of its own history as the Long March, as Savimbi and his followers headed westwards back to the Central Highlands, avoiding the towns where they were liable to run into Cuban soldiers. Mao continued to loom large in Savimbi's political imagination. In Chiwale's words: '[t]he tough journey to flee from the tentacles of our executioners came to be known in the history of our party as the Long March, because of the similarity to that of Mao Tse Tung and his companions'. ${ }^{50}$ The former associate of Savimbi quoted above took a more cynical view, describing the 'Long March' label as 'a question of marketing'. 51

Even while the MPLA controlled the towns, UNITA's officers found that they could mobilise people in the rural Central Highlands. It was during this period that the officers learnt of the death of Mao while on holiday in Namibia. After 1977, FAPLA and Cuban soldiers began to attack UNITA positions, but this did not prevent UNITA

47 F. Spies, Operasie Savannah: Angola 1975-1976 (S.A. Weermag, Direktoraat Openbare Betrekkinge, 1989), p. 149.

48 J. Muekalia, Angola: A Segunda Revolução (Lisbon, Sexante Editora, 2010).

49 Interview, former soldier, Lisbon, May 2009.

50 Chiwale, Cruzei-me, p. 221.

51 Interviewee, former soldier, Lisbon, May 2009. 
from maintaining bases across rural Angola, where it was able to apply what Savimbi had learnt from Mao, by cultivating a consensual relationship with the rural population. In the Central Highlands, these bases were within UNITA's ethnolinguistic heartland, and within attacking distance of some economically important towns. UNITA's strategy was to offer rudimentary education and health care, thus winning the trust of the people and inculcating a fear of the MPLA, against which UNITA could offer itself as a guarantor of security.

The plan included political rallies 'to mobilise the masses and their elites'. 52 Elite mobilisation included recruiting the pastors, teachers and health staff from the Protestant missions where the UNITA leaders had been educated, so that these professionals could apply their skills under the auspices of UNITA. General Nunda, who was sent by Savimbi to bring people from Dôndi mission, makes clear that they were tricked into travelling to UNITA-held zones, from which they would not be allowed to return:

[Savimbi] didn't say to me 'you will fetch the leaders for them never to return'. I went to tell the leaders that Dr Savimbi was in an area not far away, just so you can go and meet him ... and afterwards I will bring you back. When we arrived there [where Savimbi was] he told me, 'go and fetch their wives - you will find a way of bringing their families here'. Eventually I understood that I hadn't fetched the pastors for them to return afterwards. ${ }^{53}$

Professionals in UNITA's ranks were necessary in order for UNITA to provide services as a way of cementing support: 'the Chinese revolution taught that a guerrilla movement that wants to take power has to create support bases', Nunda said. This contrasted with the role of the peasantry, which 'was more the population where soldiers were recruited, the population that organised food for the troops, and also carried weapons for the troops'. UNITA officials would later use the same logic to justify the kidnapping of skilled people to work in its showcase capital, Jamba, in south-eastern Angola. As I discuss below, the existence of Jamba was central to UNITA's articulation of an ideology that linked nationalist legitimacy to a programme of state building.

Maoist influence on UNITA was confined to the practicalities of waging a guerrilla war rather than constituting a vision for a future Angola. According to Jaka Jamba: 'as we were establishing the guerrilla struggle, theories that influenced us the most were those that came from the people who had been best at making this kind of war. Hence the passion for China .... It wasn't about big doctrines'.54 Chiwale recalls Savimbi saying in 1977:

[w]e are not going to reject certain theses of Marxism completely, particularly that which says power must be seized from the bourgeois class and handed over to the worker and peasant class.... If [for the MPLA] the revolution moves from urban centres to the periphery, our perspective is the opposite, that is, one has to move from the countryside to the city, since ... we don't have a working class in the real sense of the word. ${ }^{55}$

52 Chiwale, Cruzei-me, p. 246.

53 Interview, General Nunda, Luanda, September 2009. Dôndi, near Katchiungo in Huambo province, is the best known of the Protestant missions in the Central Highlands, and is where Savimbi was educated.

54 Interview, Jaka Jamba, Luanda, September 2009.

55 Chiwale, Cruzei-me, p. 250. See also Muekalia, Angola, p. 94. 
After 1978, Savimbi turned away from China, as he became increasingly reliant on South Africa for support. ${ }^{56}$ Nevertheless, it was precisely this South African backing that enabled UNITA in the early 1980s to implement a second phase of the strategy learned from Mao: that of the secure rear base in the form of Jamba, far from the Central Highlands but close to South African-occupied Namibia.

Central to understanding UNITA's relationship with South Africa is the fact that Angolans in UNITA-controlled areas had minimal contact with South Africans. This differed from the situation in government-controlled areas where Angolan citizens frequently encountered Cuban civilian or military personnel. Hence, in contrast to the Cuban presence, which elicited a range of reactions, the lack of contact between Angolans and South Africans meant that Angolan perceptions of South Africans were determined by official prescriptions on both sides.

Moreover, while MPLA officials professed an ideological affinity with the Cubans, the same was not true for UNITA officials with respect to the South Africans. At the time of independence, UNITA already knew of the political liability that was created by South African military support. When the news was confirmed in the international media, Muekalia describes the political consequences as follows: '[i]n that context it was, politically, a mortal sin to accept any help from the racist South African regime ... the world's reaction was more emotional than rational. It was no use arguing about superior Cuban and Soviet military personnel on the other side' ${ }^{57}$ The MPLA and its sympathisers lost no opportunity to present UNITA's connection with the apartheid regime as evidence of UNITA's counter-revolutionary character. The revelation of its links with South Africa cost UNITA the sympathy of some European and most African states. ${ }^{58}$ As UNITA prepared for its Fourth Congress in 1977, it attempted some damage control by inviting the African American journalist Leon Dash, who had already spent several weeks with UNITA in 1973. In Muekalia's account, '[c]ountries and organisations that were trying to avoid confronting the complexity of the Angolan problem, hid behind this factor to justify simplifying it. For these reasons, the participation of an American journalist in this congress appeared to be of strategic importance'. ${ }^{59}$

Still today, UNITA officials try to justify the alliance with South Africa as a relationship born of desperate circumstances. In his account of the early years of the war against the MPLA, Chiwale emphasises that Savimbi was vocally opposed to apartheid and defends UNITA's decision to seek South African help as a matter of survival against a Cuban-supported MPLA ${ }^{60}$ Chiwale claims that Savimbi used the opportunity of a meeting in 1978 with South African government ministers to call for Nelson Mandela's release from prison. ${ }^{61}$ Muekalia was part of a delegation to London, an important centre of the anti-apartheid movement, in 1985. Savimbi warned Muekalia that the 'very liberal' British intelligentsia and media would challenge him on UNITA's South African links.

56 The last visit to China by a senior UNITA delegation was in 1978 (interviews, Abel Chivukuvuku and General Nunda, Luanda, 2009).

57 Muekalia, Angola, p. 41.

58 Birmingham, 'Angola', p. 147.

59 Dash's reports were published in the Washington Post on 10 and 11 August 1977. He quotes UNITA officers justifying UNITA's struggle in terms of the Cuban presence, and saying that MPLA officers and Cubans would be killed, while civilians and foot soldiers would be 're-educated'.

60 Chiwale, Cruzei-me, p. 237.

61 Ibid., pp. 251-2. 


\begin{abstract}
It was important for us to confront the question of explaining that it had to do with a coincidence of interests in the framework of geopolitics and that history had various examples of alliances of this kind: Stalin's alliance with Hitler, at the beginning of the Second World War, did not lead Stalin to adopt Nazism .... It was, above all, a question of survival.... UNITA's priority was the struggle against the Russo-Cuban occupation of Angola.... Apart from that, apartheid is a state ideology with no possibility of expansion. Even if we wanted to adopt it, against whom would we apply it?
\end{abstract}

These UNITA elite memoirs make it clear that the alliance with South Africa was a source of shame that rhetoric could not purge. Yet for people who had lived in UNITA areas and identified with the movement, there was no need to resolve the contradiction posed by UNITA's association with a racist regime, since apartheid was barely known to them. Interviewees were surprised to learn that there had been a system called apartheid under which black people were oppressed by a white government. To understand the significance of South Africa in UNITA discourses, it is first necessary to consider how UNITA sought to establish its legitimacy in the eyes of the people who lived in the areas that it controlled, namely through visible statebuilding. I will return to this point later.

Yet even while UNITA's association with South Africa and the US caused the outside world to see UNITA as a conservative movement, Muekalia's account creates a contradictory picture. Muekalia insists that 'UNITA was, and continues to be, a party ideologically of the left', recalling debates within UNITA among Marxists and Maoists. ${ }^{62}$ Yet he also echoes Savimbi's fears of Soviet expansion, a theme voiced first at the 1977 Fourth Congress. ${ }^{63}$ While, on the one hand, this resolution was strategic in terms of soliciting support from South Africa and the US, inside UNITA it was articulated in a manner that was consistent with the nationalist character that UNITA strove to present. Muekalia frames opposition to the MPLA in terms of longer histories: the MPLA sought Soviet and Cuban support because it lacked deep roots in Angolan society. The uneven penetration of colonial rule over Angola had led to the creation of a class of 'acculturated' blacks distinct from the 'indigenous' majority. This distinction, he argues, was perpetuated by an MPLA located within the assimilated class that was 'incapable of seeing the others as fellow citizens'. ${ }^{64}$

Savimbi, when he spoke to western audiences, would portray UNITA as a force for democracy, pointing out that the MPLA had avoided the multi-party elections that both parties had agreed to as part of the transition plan set out in the preindependence Alvor Accord. Savimbi would link this to narratives of African authenticity, and, while anti-communist, he did not hesitate to characterise UNITA as 'socialist': '[t]he people want to taste freedom in peace. For that they need a democratic government, elected and representing the three liberation movements, MPLA, FNLA and UNITA. The building of African socialism cannot be the same as the Castro model. We have our past, our customs'. ${ }^{65}$ In a request for South African arms and other supplies in 1976, Savimbi played to Pretoria's self-image as a bastion against communism, arguing that UNITA's struggle 'against the new domination of Soviet comunists $[\mathrm{sic}]$, must be considered as an advanced line in the defence of the Cape' at a time when 'the West has allowed Moscow to acquire a bridge in our country to launche $[$ sic $]$ new thrusts against South West Africa, South Africa, Zambia

\footnotetext{
62 Muekalia, Angola, pp. 147-9.

63 Chiwale, Cruzei-me, p. 246. See also Muekalia, Segunda Revolução, pp. 78-84.

64 Muekalia, Angola, pp. 91-2.

65 Interview with Dominique de Roux, quoted in Bridgland, Jonas Savimbi, p. 231.
} 
and Zaire' ${ }^{66}$ Thus reassured, his South African allies accepted what they understood as Savimbi's preference for 'a community oriented socialist system in which a large measure of free enterprise can take place', as opposed to 'a state oriented socialist system, on the white model, [which] he sees as unsuitable for Africa'. ${ }^{67}$ 'African socialism' was, however, absent from Savimbi's conversations with Americans, to whom Savimbi portrayed UNITA above all as an anti-communist movement. He told a visiting American journalist that 'the values and ideals that have made your country the greatest on earth are the same values and ideals that bind us together - the struggle for freedom and liberty'. ${ }^{68}$ But anti-communism was again packaged in a language of African authenticity: Marx, Savimbi opined during one visit to the United States, was 'a man of German origin, in an era dominated by French philosophy, living in Britain and dealing with the economic problems of Britain at that time'.

However chameleon-like Savimbi may have been in his appeals to foreign audiences, and whatever theoretical debates may have taken place among the UNITA elite, the ideology that UNITA presented to its adherents inside Angola was consistent. UNITA, like the MPLA, based its legitimacy on its ability to make statelike claims, claims based on responsibilities of social organisation and welfare provision, and on prerogatives of violence in defence of a nation that was constructed in the image of a political movement. 70 The very fact of sustaining a de facto diplomatic relationship with the dominant regional power was, in the eyes of the UNITA elite, affirmation of the movement's state-like potential. But for most of UNITA's adherents, the movement's aspirations to statehood were most convincingly embodied in Jamba, the bush capital in Cuando Cubango province that existed from the early 1980s until the end of the 20th century. Jamba's military significance to UNITA is well established, but my concern here is rather with its symbolic and ideological importance. According to those interviewees who spent time there, Jamba was 'almost like a city' or 'a state within a state'. 'Health matters were looked after for free ... Education too... If an individual were sick, they would go to hospital without paying. We were self-sufficient for food from agriculture, but there was also help from the party'.71 Even interviewees who by their own account had been kidnapped from government-held zones and taken to Jamba, and who had no prior affiliation to UNITA, emphasised the social organisation and service provision at Jamba as an indication of UNITA's worth as an alternative government: 'life was good in Jamba.... They had means - vehicles came from South Africa with enough food.... It looked like a bairro but it was organised like a city. There were roads of beaten earth. The hospitals were well organised'.72 Its hospitals, schools, international air links and diplomatic visits by US or South African officials were evoked by interviewees as a token of UNITA's potential as a government in waiting. It was in this sense that UNITA's internal ideology - a complex of normative ideas

66 South African Department of Defence Archives, Minister van Verdediging, box 102 Angola Verslae, Office of the Head of the State Intelligence P18/14/6, 'Brief van Dr Savimbi', undated (probably 1976).

67 South African Department of Defence Archives, Minister van Verdediging, box 102 Angola Verslae, MV 56/6/1, Office of the Head of the South African Defence Force HSAW 520/2/2, 'Vervoer van UNITA-Leiers van RSA na Zaire', 20 September 1977.

68 Bridgland, Jonas Savimbi, p. 335.

69 Ibid., pp. 289-90.

70 I discuss this more fully in J. Pearce, Political Identity and Conflict in Central Angola: 1975-2002

(Cambridge, Cambridge University Press, 2015).

71 Interview, former soldier, Huambo, June 2008

72 Interview, catechist, Huila, November 2008. 
linking stateness to political legitimacy, embodied in Jamba - succeeded in winning the approval of people who knew nothing about UNITA's foreign allies. To them, South Africa was simply a benign ally in a project led by UNITA, 'a foreign element with technology, for Angolans to develop'.73

On the MPLA side, South African support for UNITA, as well as UNITA's links to the US, made it possible for the MPLA, long after the departure of the Portuguese, to present its own political agenda as a nationalist, anti-colonial and antiracist one, and to assert that the Angolan conflict was not about internal divisions, but a struggle by the MPLA to defend the nation against foreign invasion. Some MPLA supporters, including government officials, still insist that there was never a civil war in Angola: only a foreign invasion by South Africa with the US as its patron and with UNITA as its proxy. ${ }^{74}$ Construction of the enemy as imperialist and racist closed the door on discussion of the class position and ethnic affiliations of the MPLA leadership, attributes that threatened to disrupt the MPLA's claims to inclusivity. Savimbi's rhetoric played on these attributes, characterising the MPLA as led by a mestiço and assimilado elite that was more Portuguese than African. ${ }^{75}$

\section{Conclusion}

The accounts presented by Angolans who remember the conflict of the 1970s and 1980s suggest a complex relationship between the presence of foreign interests in the conflict, the ways in which their presence was represented in elite political discourses on both sides of the conflict, the ways in which the foreign presence was represented in popular discourse, and the ways in which the foreign presence shaped adherence to one or other party. The official ideologies that defined the global confrontation between the US and the Soviet Union were refracted through a prism of Angolan contingencies, identities and loyalties. Only on the MPLA side of the conflict, and chiefly among educated town dwellers, was there an awareness of the ideological orientation of the party's allies in global politics. This was possible because, even if the MPLA leadership's relationship with Cuba was driven in part by the desire for survival, the political language used by the MPLA inside Angola was congruent with the discourse of socialist internationalism offered by Castro's Cuba. In contrast, UNITA had little possibility of making ideological appeals directly based on its foreign connections, given the movement's association with an eclectic range of foreign allies over the years. The legacy of Maoism animated the UNITA elite in their imagination of a popular peasant revolution, but meant little to peasants themselves. South African support was an embarrassment that UNITA officials struggled to justify, while UNITA's western links were echoed only in loosely defined ideas of 'freedom'.

But on both sides, more politically significant than the rival ideological visions of the Cold War were the realities of external intervention in Angola, irrespective of ideological orientation, which enabled the efforts by the rival Angolan leaders to shape popular perceptions and beliefs to their own political ends. Although the Cuban engagement with Angolan society was of an entirely different nature from the South African involvement, there was a symmetry in the political consequences of the foreign links on both sides. Foreign military backing provided security for each side. But of greater political significance was the foreign assistance in creating physical

73 Interview, former soldier, Huambo, June 2008.

74 Conversation with government official, Huambo, July 2008.

75 'Mestiço' refers to a person of mixed race, and 'assimilado' to a black person who, under colonial rule, had achieved the status of being 'assimilated' into Portuguese culture. 
infrastructure and providing the services that enabled each movement to present itself as a state and to construct legitimacy for itself through exercising state-like prerogatives and responsibilities. If, as Westad observes, Soviet or US versions of high modernism provided the inspiration for postcolonial state building, ${ }^{76}$ Angolan political elites benefited from foreign assistance in implementing modernist visions, but took care to assert, above all, their ownership of these processes of state-building in such a way as to consolidate their authority at local level.

The presence of foreign participation in the conflict also had consequences beyond and sometimes contrary to the political strategies of the warring parties. Asked to explain the antipathy that certain Angolans expressed for the Cubans who had been in the country in the 1970s, a Protestant pastor interviewed in Huambo offered this explanation:

that hatred - a person feels it towards all those who helped to continue the war. Because if it were not for them, there would not have been the war that we waged. The South Africans as much as the Cubans helped to prolong our war. So I think it's natural that certain people have this feeling. ${ }^{77}$

External involvement in the Angolan conflict polarised opinion and deepened hostility, sentiments that could be exploited politically by the Angolan parties to the conflict. Both UNITA and the MPLA invoked the presence of foreign forces on the opposite side of the war to reinforce the view of the adversary as the agent of an external enemy, and hence to deepen their own exclusive nationalist claims. Yet their ability to do so depended on them having the capacity to promote their preferred interpretation of events. The foreign presence in Angola could reinforce the legitimacy of the Angolan movements, but also undermine it. Among those who were not touched by the efforts at politicisation from either side, the foreign involvement also contributed to a sense of alienation from the conflict, a suspicion of the intentions of both the Angolan adversaries, and ultimately a suspicion of all things political.

\section{Acknowledgements}

This article is based in part on research conducted in the course of doctoral studies at St Antony's College, Oxford. I acknowledge the financial support that I received from the ORISHA fund, the Department of Politics and International Relations at Oxford, and St Antony's College. I am currently supported by a Leverhulme Early Career Fellowship, research grant number 74978. The themes in the article were developed in conference papers at the Working Expert Seminars on Southern Africa in the Cold War Era, hosted in Lisbon by the LSE Cold War Studies Centre and the Instituto Português de Relações Internacionais in 2009 and 2010, and at the JSAS conference in Livingstone in 2015. I acknowledge the support of the Santander Student Travel Fund and of $J S A S$ in attending these events, and I am grateful for the useful input of fellow participants in the conferences and of two anonymous peer reviewers.

\section{Justin PEARCE}

Leverhulme Early Career Fellow, Department of Politics and International Studies, 7 West Road, Cambridge CB3 9DT, UK, and Research Associate at St John's College, Cambridge.E-mail: justin.pearce@gmail.com

76 Westad, Global Cold War, p. 397.

77 Interview, pastor, Huambo, May 2008. 